\title{
An Evaluation of Simultaneous Openness Hypothesis in the Context of Stock Market Development: Evidence from a Panel of Fifty Three Countries Based a GMM Study
}

\author{
Z. T. Abdallah \\ Department of Economics, Faculty of Social and Management Sciences, Kaduna State University, Kaduna State, \\ Nigeria \\ Email: zubairutajo@yahoo.com
}

Received 12 December 2015; accepted 16 February 2016; published 19 February 2016

Copyright (C) 2016 by author and Scientific Research Publishing Inc.

This work is licensed under the Creative Commons Attribution International License (CC BY).

http://creativecommons.org/licenses/by/4.0/

c) (i) Open Access

\begin{abstract}
This paper focuses on the impact of the concurrent liberalization of current and capital accounts and quality institutions on stock market development. Using annual data from 1996-2013 for a panel of fifty three (53) developed and developing countries and utilizing dynamic GMM estimators, the results show that banking sector development, economic growth, and the interaction term affect stock market development positively. The paper finds that capital account liberalization affects market development negatively, but the effect of capital account liberalization on market development is contingent on the level of economic growth and development. Further, the results revealed that the impact of trade openness on stock market development is mixed. The research finds negative impact of institutional factors on market development. Finally, the paper does not find support in favour of simultaneous openness hypothesis.
\end{abstract}

\section{Keywords}

Simultaneous Openness Hypothesis, Institutional Factors, Financial Sector Development, Principal Component, GMM

\section{Background}

One important issue at the centre of financial development and economic growth studies is that of the determinants of financial sector development. Factors such as financial and trade liberalization, quality institutional factors etc are argued to affect financial sector development [1] [2]. Specifically, studies on liberalization, espe- 
cially financial sector liberalization, are few and mixed [1] [3]. Rajan and Zingales [4] proposed the simultaneous openness hypothesis, where they argued for the concurrent opening of trade and capital account, in order to generate and realize the gains of liberalization on financial sector development and hence, economic growth.

While there is strong support for the positive impact of institutional factors on financial sector development, yet there are some contrary empirical findings [5]. Another factor of importance in openness-financial sector development nexus is the level/stage of economic development. Economic growth may exert influence on openness-finance relationship (Presbisch-Singer, 1950).

For instance, while trade between developed countries may be seen as trade between or among equal partners, trade between developing and developed countries may be seen as trade between unequal partners. Therefore, the gains of trade liberalization in these two cases may differ between and among countries [6] [7]. Therefore, it is important, while examining the relationship between liberalization and financial sector development to take into account countries' levels of economic development.

Finally, one major problem confronting studies on financial sector development is that of the choice of appropriate measures of financial sector development. There are several measures of financial sector development, with each having its merits and demerits. This study hopes to address this challenge by constructing principal component, from three measures each, of banking sector and stock market development.

This paper examines overall, the impact of liberalization and institutional quality on stock market development.

The rest of the paper is organized as follows: Section 2 is the literature review, Section 3 discusses the methodology of our work, Section 4 presents and analyses our results, finally, Section 5 concludes.

\section{Empirical Literature}

While there is strong support for the positive impact of institutional factors on financial sector development [8] [9], empirical results on liberalization on financial sector development are mixed and contentious [10] [11]. Below are some of the studies reviewed.

\begin{tabular}{|c|c|c|c|c|}
\hline $\mathbf{S} / \mathbf{N}$ & AUTHOR(S) & OBJECTIVE & METHODOLOGY & FINDINGS \\
\hline 1 & Law (2008) [1] & $\begin{array}{l}\text { Examined the role trade } \\
\text { and capital openness on } \\
\text { financial sector } \\
\text { development in } \\
\text { Malaysia }\end{array}$ & ARDL based on ECM & $\begin{array}{l}\text { Rule of law, Trade and capital account openness } \\
\text { positively affect banking sector development, but the } \\
\text { interaction term is insignificant. Rule of law, Trade and } \\
\text { Capital account openness are insignificant determinants } \\
\text { of stock market development. In the short run however, } \\
\text { openness to trade and Capital account negatively affect } \\
\text { financial sector development while the interaction term } \\
\text { promotes financial sector development. }\end{array}$ \\
\hline 2 & $\begin{array}{l}\text { Law and Shah } \\
\text { Habibullah } \\
\text { (2009) [8] }\end{array}$ & $\begin{array}{l}\text { Investigate the role of } \\
\text { institution, Trade and } \\
\text { Financial liberalization } \\
\text { on financial } \\
\text { development }\end{array}$ & $\begin{array}{l}\text { Using annual data from } \\
\text { 1980-2001, in a panel } \\
\text { of } 27 \text { countries. Using } \\
\text { dynamic GMM and } \\
\text { Pooled Mean Group }\end{array}$ & $\begin{array}{l}\text { Institutional factors and trade openness are important } \\
\text { determinants of both banking and stock market } \\
\text { development. The impact of financial liberalization is } \\
\text { mixed. }\end{array}$ \\
\hline 3 & $\begin{array}{l}\text { Chin and Ito } \\
\text { (2003) [2] }\end{array}$ & $\begin{array}{l}\text { Examined the impact of } \\
\text { financial openness on } \\
\text { financial development }\end{array}$ & $\begin{array}{l}\text { Using annual data from } \\
1980-2000 \text { in a panel of } \\
108 \text { countries }\end{array}$ & $\begin{array}{l}\text { Financial openness promotes stock market development. } \\
\text { Legal development, trade openness, and banking sector } \\
\text { development are pre-conditions for capital account } \\
\text { openness. Certain threshold of legal development } \\
\text { especially general laws is important to stock market } \\
\text { development. Banking sector and stock market } \\
\text { developments are complementary. }\end{array}$ \\
\hline 4 & $\begin{array}{l}\text { Ben-Naceau, } \\
\text { Ghazouani, and } \\
\text { Omran (2008) } \\
{[11]}\end{array}$ & $\begin{array}{l}\text { Probed the effect of } \\
\text { stock market } \\
\text { liberalization on } \\
\text { economic growth }\end{array}$ & $\begin{array}{l}\text { Using annual data from } \\
\text { 1979-2005 among } 11 \\
\text { MENA countries and } \\
\text { employing System } \\
\text { GMM and } \\
\text { Non-Parametric } \\
\text { methods. }\end{array}$ & $\begin{array}{l}\text { Financial liberalization leads to improvement in the } \\
\text { financial sector. Financial liberalization affects stock } \\
\text { market development negative and positive in the short } \\
\text { and long runs respectively. Stock market liberalization is } \\
\text { insignificant to private investment. Developed stock } \\
\text { market, trade openness, and less government intervention } \\
\text { are prerequisite to stock market liberalization. }\end{array}$ \\
\hline 5 & $\begin{array}{l}\text { Demetriades } \\
\text { and Luintel } \\
(2007)[3]\end{array}$ & $\begin{array}{l}\text { Investigate the cost of } \\
\text { financial repression in } \\
\text { India. }\end{array}$ & $\begin{array}{l}\text { Using annual data from } \\
1960-1991 \text { and by } \\
\text { means of VECM } \\
\text { (DOLS and SOLS). }\end{array}$ & $\begin{array}{l}\text { Repression has substantial negative impact on financial } \\
\text { sector development, and economic growth. }\end{array}$ \\
\hline
\end{tabular}




\section{Continued}

\begin{tabular}{|c|c|c|}
\hline 6 & $\begin{array}{l}\text { Bekeart, } \\
\text { Harvey, and } \\
\text { Lundbland } \\
(2005)[12]\end{array}$ & $\begin{array}{l}\text { Investigate the impact } \\
\text { of stock market } \\
\text { liberalization on } \\
\text { financial development } \\
\text { and economic growth. }\end{array}$ \\
\hline 7 & $\begin{array}{l}\text { Goh, Alias, and } \\
\text { Olekalns } \\
\text { (2003) [13] }\end{array}$ & $\begin{array}{l}\text { Investigate the role of } \\
\text { external factors and } \\
\text { trade openness on } \\
\text { interest rate } \\
\text { determination }\end{array}$ \\
\hline 8 & $\begin{array}{l}\text { Levine and } \\
\text { Zervos (1998) } \\
{[14]}\end{array}$ & $\begin{array}{l}\text { Examined the effect of } \\
\text { capital control } \\
\text { liberalization on stock } \\
\text { market development }\end{array}$ \\
\hline 9 & $\begin{array}{l}\text { Beck and } \\
\text { Levine (2005) } \\
\text { [5] }\end{array}$ & $\begin{array}{l}\text { Examined the impact of } \\
\text { legal institutions on } \\
\text { financial development }\end{array}$ \\
\hline
\end{tabular}

Using annual data from 1960-2004 in a sample of 16 Sub Saharan African countries. Utilizing Granger Causality based on Hsiao, Bi-Variate, and Tri-Variate VAR/VECM (2010) [16] Suardi (2009) [17] (2011) [18]

Using annual data from 1991-2005 in a sample of emerging markets on volatility of stock market returns

Using annual data from 1971-2005 in a sample of 25 Sub Saharan African countries and employing panel OLS and System GMM

Probed the dynamic effect of trade openness on financial development

Using annual data from 1960-2005 in a panel of 88 countries and using Pooled Mean group
Using annual data from 1980-1997 in a panel of 95 countries. Employing and GMM

Using quarterly data from 1973Q1-1985Q3 991Q1-1998Q3 in Malaysia. Adopting Edward and Khan Model

a sample of 6 emerging countries and using Unit root and Simple Comparism.

Stock market liquidity tends to increase liberalization of international capital control. Ease and accessibility of information is positively associated with stock market development. Countries with good accounting standards, investors' protection laws tend to have better and more developed stock markets.

Differences in legal tradition influence countries' attitudes on private property rights protection, support for private contractual arrangements, the enactment and enforcement of investors' protection laws. Institutions shape the willingness to save, invest, the effectiveness of the corporate governance, and the degree of financial market development

Demand following relationship dominates. Only few cases points to supply leading relationship, while in few other cases, there is no significant relationship between financial deepening and economic growth.

There is positive relationship between the degree of financial liberalization and global volatility. There is negative relationship between volatility and financial liberalization after controlling for stock market development, liquidity, countries effect, and crisis effect.

Financial liberalization leads to lower volatility in output and consumption growth. Trade openness leads to economic instability. The effect of liberalization on volatility is contingent on the degree of financial development and institutional quality.

Trade openness affect financial development negatively in the short run but positively in the long run. The effect of trade openness is dependent on inflation rate and income level. There is negative short run but positive long run impact of trade openness on financial development in relatively low income and high inflation countries. There is insignificant short run but negative long run impact of trade openness on financial development in high income countries. The effect of trade openness on financial development is mixed in low inflation countries.

Openness and economic institutions are important determinant of financial sector development. There is mixed evidence for simultaneous openness hypothesis. 
Continued

\begin{tabular}{|c|c|c|c|c|}
\hline 15 & $\begin{array}{l}\text { Lim and Kim } \\
{[18]}\end{array}$ & $\begin{array}{l}\text { Investigate the link } \\
\text { between trade openness } \\
\text { and informational } \\
\text { efficiency of stock } \\
\text { market }\end{array}$ & $\begin{array}{l}\text { Using monthly data } \\
\text { from } 1992 \mathrm{Q} 1-2006 \mathrm{Q} 12 \\
\text { in a sample of } 23 \\
\text { developing countries } \\
\text { and employing Fixed } \\
\text { Effect Regression }\end{array}$ & $\begin{array}{l}\text { De-factor trade openness is associated with high degree } \\
\text { of informational efficiency in emerging markets but the } \\
\text { positive effect does not hold when the De-jure measure } \\
\text { of trade openness is used. There is no evidence for } \\
\text { significant link between trade openness and stock market } \\
\text { efficiency. }\end{array}$ \\
\hline 16 & $\begin{array}{l}\text { Bley and Saad } \\
\text { (2011) [19] }\end{array}$ & $\begin{array}{l}\text { Assesses the impact of } \\
\text { equity market } \\
\text { liberalization and } \\
\text { capital account } \\
\text { openness on individual } \\
\text { firm's stock return } \\
\text { volatility }\end{array}$ & $\begin{array}{l}\text { Using annual data from } \\
\text { 1998-2009 Gulf } \\
\text { Cooperation Council } \\
\text { markets for } 602 \text { stocks } \\
\text { and utilizing pooled } \\
\text { regression }\end{array}$ & $\begin{array}{l}\text { Capital account openness significantly reduces volatility } \\
\text { especially for stocks with low foreign ownership limits. } \\
\text { The effect of capital account restrictions is stronger on } \\
\text { capital inflow than outflow and on residents than } \\
\text { non-residents }\end{array}$ \\
\hline
\end{tabular}

\section{Methodology}

\subsection{Model Specification}

Following Law and Shah Habibullah [8], we present our model as thus:

$$
P C S_{i t}=\beta_{0 i t}+\beta_{1} P C S_{i, t-1}+\beta_{2} P C B_{i t}+\beta_{3} Y_{i t}+\beta_{4} T O_{i t}+\beta_{5} C A O_{i t}+\beta_{6} I N S T_{i t}+\mu_{i}
$$

where PCS, PCB, Y, TO, CAO, INST, and $\mu$ denote principal component of stock market development, principal component of banking sector development, economic growth, trade openness, capital account openness, institutional factor, and the error term respectively. Economic growth is measured by real GDP per capita while institutional factor is represented by an index of institutional quality, constructed from four measures namely, corruption control, bureaucracy, voice and accountability, and government effectiveness, and assumes a value of less or equal to 40. Stock market development is measured by the principal component of stock market development, constructed from the ratios of stock market capitalization to GDP, total value traded to GDP, and the turnover ratio. Banking sector development is measured by the principal component of banking sector development, constructed from the ratios of liquid financial liability to GDP, credit to the private sector by the deposit money bank to GDP, and deposit money bank assets to the deposit plus central bank assets. Trade openness is proxied by the ratio of the sum of export plus import to GDP. Capital account openness is measured by the Capital Account Openness Index, adopted from Chinn and Ito [2].

Following the argument that financial liberalization may boost financial sector development and economic growth if accompanied by other economic and institutional reforms such as stable macroeconomic conditions, political and policy stability, trade liberalization, etc Rajan and Zingales [4] have in addition proposed the simultaneous openness hypothesis. Hence, to capture this, we interact our openness variables (trade and capital account) and therefore re-specify our model as thus below:

$$
P C S_{i t}=\beta_{0 i t}+\beta_{1} P C S_{i, t-1}+\beta_{2} P C B_{i t}+\beta_{3} Y_{i t}+\beta_{4} T O_{i t}+\beta_{5} C A O_{i t}+\beta_{6} I N S T_{i t}+\beta_{7} I N T_{i t}+\mu_{i t}
$$

where INT is the interaction term, all other variables are as defined above.

To measure the effect of financial openness on financial sector development after controlling for country's stage/level of development, we introduce dummies $\left(d_{1}\right.$ and $\left.d_{2}\right)$ for developed and developing respectively and interacts the dummies with measure of capital account openness. Therefore, our new models after controlling for stage of development is specified as thus below:

$$
\begin{aligned}
& P C S_{i t}=\beta_{0 i t}+\beta_{1} P C S_{i, t-1}+\beta_{2} P C B_{i t}+\beta_{3} Y_{i t}+\beta_{4} T O_{i t}+\beta_{5} C A O_{i t}+\beta_{6} I N S T_{i t}+\beta_{7} I N T_{i t}+\beta_{8} d_{1} C A O i t+\mu_{i t} \\
& P C S_{i t}=\beta_{0 i t}+\beta_{1} P C S_{i, t-1}+\beta_{2} P C B_{i t}+\beta_{3} Y_{i t}+\beta_{4} T O_{i t}+\beta_{5} C A P_{i t}+\beta_{6} I N S T_{i t}+\beta_{7} I N T_{i t}+\beta_{5} d_{2} C A O_{i t}+\mu_{i t}
\end{aligned}
$$

\section{Principal Component}

Principal component analysis is a mathematical method which recognises patterns in datasets in a way that highlight similarities and differences in the original datasets while retaining most of the information contained in the original datasets in the principal component (Smith, 2002). It is defined as a statistical method that simplifies complex datasets by reducing the dimension of their matrix, where the reduced data matrix accounts for most of 
the variations in the original datasets/matrix while at the same time mutually uncorrelated and orthogonal (Raychaudhuri et al., 2000).

Principal component analysis models the structure of the variations of a number of variables using their linear combinations known as the components, which can be used for further analysis. This approach is appropriate if we wish to develop a smaller number of artificial measures from a large number of observed measures that will account for most of the changes in the original observed variables. In addition, it addresses the problem of multi-collinearity in our study.

\subsection{Method of Estimation}

This paper uses Dynamic Panel Generalized Method of Moment estimators (hereafter GMM) as proposed by Holtz-Eakin et al. (1988) and later extended by Blundell and Bond [20]. These estimators are most applicable in a panel data with large cross sectional observations and small time series observations. Again, the strength of the estimators over other dynamic panel estimators, especially in addressing the problems of endogeneity, simultaneity, individual effect, the likelihood of obtaining a consistent parameter estimates etc. are other reasons for the selection of these estimators.

GMM is defined as the moment conditions formed under the assumptions that particular lagged levels of the dependent variables are uncorrelated to the difference disturbances [21], constructed from the further lags of the levels of the dependent variable and the first difference of the error and the explanatory variables, and that the disturbances are identically and independently distributed over the cross sectional units and time (Holt-Eakin, 1988). It weight the vector of the sample mean of the moment conditions by a positive definite matrix and if the matrix is the covariance matrix of the moment conditions, GMM estimators are said to be efficient estimators.

If we take the difference of the level equations so as to remove the unobserved individual effects, the resulting equation is known as the Difference GMM estimator, presented as below;

$$
Y_{i t}-Y_{i, t-1}=\alpha\left(Y_{i, t-1}-Y_{i, t-2}\right)+\beta\left(X_{i t}^{*}-X_{i, t-1}^{*}\right)+\left(\varepsilon_{i t}-\varepsilon_{i, t-1}\right)
$$

where $X^{*}$ are exogenous variables. Based on the condition above, the lagged levels of the explanatory variables are used as instruments for the difference equations [21]. Therefore, we set our first difference moment conditions as

$$
\begin{aligned}
& \mathrm{E}\left[\left(Y_{i t-s}\right) *\left(\varepsilon_{i t}-\varepsilon_{i, t-1}\right)\right]=0, \text { for } s \geq t, t=3, \cdots, T \\
& \mathrm{E}\left[\left(X_{i t-s}^{*}\right) *\left(\varepsilon_{i t}-\varepsilon_{i, t-1}\right)\right]=0, \text { for } s \geq t, t=3, \cdots, T
\end{aligned}
$$

Arellano and Bover [22] proposed an alternative and more efficient GMM estimator that combines together both the difference and level equations, known as the System GMM. This estimator combines the moment conditions for the difference equations with that of the level equations and utilizes the assumptions about the initial conditions to generate a moment condition that is still informative even in the presence of persistence series (Blundell and Bond, 1998). The System GMM model is presented as thus below:

$$
Y_{i t}=\alpha_{1} Y_{i, t-1}+\alpha_{1} X_{i, t-1}^{*}+\left(\mu_{i}-\gamma_{i}\right)
$$

where $\mu$ and $\gamma$ are the individual specific effect which is invariant to time and the error term respectively. Following Arellano and Bover [22], we set our moment conditions for the System GMM as below;

$$
\begin{aligned}
& \mathrm{E}\left[\left(Y_{i, t-s}-Y_{i, t-s-1}\right) *\left(\mu_{i}-\varepsilon_{i t}\right)\right]=0, \text { for } s=1 \\
& \mathrm{E}\left[\left(X_{i, t-s}^{*}-X_{i, t-s-1}^{*}\right) *\left(\mu_{i}-\varepsilon_{i t}\right)\right]=0, \text { for } s=1
\end{aligned}
$$

\subsection{Data}

Annual data from 1996-2013 averaged over three (3) years (thus giving us time series data of 6 years) in a sample of fifty three countries was used. Data on measures of institutional quality is collected from World Bank Governance Indicator database. Data on measures of banking sector and stock market developments are collected from financial structure database. Data on economic growth and trade openness are collected from World 
Bank Development Indicator database. Data on capital account openness is obtained from Chinn and Ito. Data on principal component of banking and stock market development are constructed from three measures of banking and stock market development each respectively.

\section{Presentation and Discussion of Finding}

Table 1 shows the result of the impact of openness and institutions on financial sector development. From the table, the results reveal that banking sector development, growth, trade openness, and the measure of the interaction term affect stock market development positively while capital account openness and institutional factors affect stock market development negatively.

Table 2 displays the result of the impact of capital account openness and institutional factor on stock market development in developed countries. From the table, the results show that banking sector development, economic growth and the interaction term positively impact on stock market development. On the other hand, capital account openness and institutional factor negatively affect stock market development. Trade openness is found to be insignificant to stock market development. Interestingly, the results show that capital account openness in developed countries has positive impact and hence, promote stock market development.

Table 3 depicts the results of openness and institutional factor on stock market development in developing countries. From the table, the results show that banking sector development, economic growth, and measure of simultaneous openness positively impact on stock market development. On the contrary, capital account openness and measure of institutional quality deter stock market development. Trade openness is insignificant to stock market development. The results further reveal that capital account liberalization in developing countries affects stock market development negatively.

Table 1. The result of two step dynamic panel GMM on the role of financial and trade openness on financial development (sample period: 1996-2013, averaged over 3 years).

\begin{tabular}{ccc}
\hline & TWO STEP DIFFERENCE GMM & TWO STEP SYSTEM GMM \\
\hline \multirow{2}{*}{ PCS $_{t-1}$} & $0.7714^{* * * *}$ & $0.5459^{* * *}$ \\
& $(0.115)$ & $(0.0687)$ \\
PCB & {$[0.000]$} & {$[0.000]$} \\
& $0.0023^{* * *}$ & $0.0025^{* * *}$ \\
& $(0.0005)$ & $(0.0003)$ \\
LY & {$[0.004]$} & {$[0.000]$} \\
& $1.9301^{* * *}$ & $1.621^{* * *}$ \\
& $(0.203)$ & $(0.1507)$ \\
LTO & {$[0.000]$} & {$[0.000]$} \\
& $5.4322^{* * *}$ & $4.2203^{* * *}$ \\
& $(1.102)$ & $(0.5491)$ \\
LCAO & {$[0.000]$} & {$[0.000]$} \\
& -8.0283 & $-8.9749^{* *}$ \\
& $(5.8971)$ & $(4.0329)$ \\
LINST & {$[0.201]$} & {$[0.002]$} \\
& $-7.3512^{* * *}$ & $-8.0331^{* * *}$ \\
& $(1.0032)$ & $(1.0081)$ \\
INT & {$[0.000]$} & {$[0.000]$} \\
& 2.2521 & $2.0414^{* * *}$ \\
AR 2 & $(1.1057)$ & $(0.6530)$ \\
& {$[0.046]$} & {$[0.004]$} \\
& $-2.5461^{* * *}$ & -1.9861 \\
& {$[0.0501]$} & {$[0.1079]$} \\
& 9.4548 & 16.2450 \\
& {$[0.1023]$} & {$[0.0884]$} \\
\hline
\end{tabular}

NOTE; LY = log of real GDP per capita, PCB = principal component of banking sector development, PCS = principal component of stock market development, ltrade $=\log$ of trade openness, LCAO $=\log$ of capital account openness, LINST $=\log$ of institutional quality, LINT = simultaneous opening of trade and capital accounts. $\mathrm{N}=53$. Values in ( ) and [ ] denotes standard errors and p-values respectively. The sign ${ }^{* * *}$ and ${ }^{* * *}$ denotes significance at $1 \%$ and $5 \%$ respectively. 
Table 2. The result of two step dynamic panel GMM on the role of financial and trade openness on financial development with a dummy for developed countries (sample period: 1996-2013, averaged over 3 years).

\begin{tabular}{|c|c|c|}
\hline & TWO STEP DIFF GMM & TWO STEP SYSTEM GMM \\
\hline $\mathrm{PCS}_{t-1}$ & $\begin{array}{c}0.298 \\
(0.105) \\
{[0.0024]}\end{array}$ & $\begin{array}{c}0.2699 \\
(0.1006) \\
{[0.008]}\end{array}$ \\
\hline LY & $\begin{array}{c}2.254 \\
(0.3412) \\
{[0.000]}\end{array}$ & $\begin{array}{c}1.7567 \\
(0.3301) \\
{[0.000]}\end{array}$ \\
\hline PCB & $\begin{array}{c}0.0197 \\
(0.0004) \\
{[0.000]}\end{array}$ & $\begin{array}{l}0.0215 \\
(0.000) \\
{[0.000]}\end{array}$ \\
\hline LTO & $\begin{array}{c}-0.5746 \\
(1.0074) \\
{[0.446]}\end{array}$ & $\begin{array}{c}-1.3397 \\
(0.7116) \\
{[0.069]}\end{array}$ \\
\hline LCAO & $\begin{array}{c}-15.3796 \\
(3.789) \\
{[0.000]}\end{array}$ & $\begin{array}{c}-10.8811 \\
(1.9028) \\
{[0.000]}\end{array}$ \\
\hline INT & $\begin{array}{c}2.9098 \\
(0.7417) \\
{[0.000]}\end{array}$ & $\begin{array}{c}2.0021 \\
(0.5236) \\
{[0.000]}\end{array}$ \\
\hline LINST & $\begin{array}{c}-1.6143 \\
(0.4910) \\
{[0.000]}\end{array}$ & $\begin{array}{c}-1.6552 \\
(0.3392) \\
{[0.000]}\end{array}$ \\
\hline D1CAO & $\begin{array}{c}7.4897 \\
(1.1245) \\
{[0.000]}\end{array}$ & $\begin{array}{c}2.0679 \\
(0.4996) \\
{[0.000]}\end{array}$ \\
\hline SARGAN TEST & $\begin{array}{l}19.9897 \\
{[0.0295]}\end{array}$ & $\begin{array}{l}23.5695 \\
{[0.5717]}\end{array}$ \\
\hline AR 2 & $\begin{array}{l}-0.8907 \\
{[0.4825]}\end{array}$ & $\begin{array}{l}-0.9904 \\
{[0.4433]}\end{array}$ \\
\hline
\end{tabular}

NOTE; LY = log of real GDP per capita, PCB = principal component of banking sector development, PCS = principal component of stock market development, LTO $=\log$ of trade openness, LCAO $=\log$ of capital account openness, LINST $=\log$ of institution, Int = simultaneous opening of trade and capital accounts, D1 = dummy for developing countries. $\mathrm{N}=53$. Values in ( ) and [ ] denotes standard errors and p-values respectively. ${ }^{* * *},{ }^{* *}$ denotes significance at $1 \%$ and $5 \%$ respectively.

\subsection{Robust Tests}

Robust tests were run to check the consistency of the findings. The measure of institutional quality was substituted with two other measures (government effectiveness and voice and accountability). The results of the robust tests are identical to those in Tables 3-5. The results of the robust tests are presented in Table 4 and Table 5.

\subsection{Analysis of Finding}

The finding of a positive impact of economic growth on stock market development is expected. It is argued that as household income increases to certain level, there will be portfolio adjustment and their demand for financial and capital assets increases. This will lead to increase in the activities of the stock market and therefore, promotes stock market development. This finding is consistent with Chakraborty [23], Zang and Kim (2007).

The finding of a positive effect of banking sector development on stock market is equally expected. Banking sector performs certain functions that are important to stock market development such as the provision of margin loans to stock brokers. This therefore justifies the positive impact of banking sector development on stock market development. This result is in line with Chinn and Ito [2] and Mansor [24].

One area of our finding that is of great empirical contention is openness and stock market development. First, proponents of trade openness argued that it will increase investment, growth, and finally leads to stock market development. Opponents of trade openness on the other hand contest that it will lead to the collapse of infant firms, which will lower investment and growth, increase unemployment, and consequently deter stock market 
Table 3. The result of two step dynamic panel GMM on the role of financial and trade openness on financial development with a dummy for developing countries (sample period: 1996-2013, averaged over 3 years).

\begin{tabular}{|c|c|c|}
\hline & TWO STEP DIFF GMM & TWO STEP SYSTEM GMM \\
\hline $\mathrm{PCS}_{t-1}$ & $\begin{array}{c}0.3980 \\
(0.1142) \\
{[0.004]}\end{array}$ & $\begin{array}{c}0.3671 \\
(0.1009) \\
{[0.001]}\end{array}$ \\
\hline LY & $\begin{array}{c}2.5752 \\
(0.4304) \\
{[0.000]}\end{array}$ & $\begin{array}{c}1.9871 \\
(0.3445) \\
{[0.000]}\end{array}$ \\
\hline PCB & $\begin{array}{c}0.1932 \\
(0.0002) \\
{[0.000]}\end{array}$ & $\begin{array}{c}0.1084 \\
(0.0002) \\
{[0.000]}\end{array}$ \\
\hline LTO & $\begin{array}{c}-0.5976 \\
(1.0005) \\
{[0.535]}\end{array}$ & $\begin{array}{c}-0.5232 \\
(0.3652) \\
{[0.251]}\end{array}$ \\
\hline LCAO & $\begin{array}{c}-8.5009 \\
(2.7632) \\
{[0.000]}\end{array}$ & $\begin{array}{c}-9.2253 \\
(2.2466) \\
{[0.000]}\end{array}$ \\
\hline INT & $\begin{array}{c}2.6156 \\
(0.5522) \\
{[0.000]}\end{array}$ & $\begin{array}{c}2.7318 \\
(0.6013) \\
{[0.000]}\end{array}$ \\
\hline LINST & $\begin{array}{c}-1.6001 \\
(0.3219) \\
{[0.000]}\end{array}$ & $\begin{array}{c}-1.5307 \\
(0.2102) \\
{[0.000]}\end{array}$ \\
\hline D2CAO & $\begin{array}{c}-6.9879 \\
(1.0319) \\
{[0.000]}\end{array}$ & $\begin{array}{c}-1.2146 \\
(0.3408) \\
{[0.002]}\end{array}$ \\
\hline SARGAN TEST & $\begin{array}{l}20.9101 \\
{[0.0305]}\end{array}$ & $\begin{array}{l}22.8437 \\
{[0.5301]}\end{array}$ \\
\hline AR 2 & $\begin{array}{l}-1.2472 \\
{[0.4632]}\end{array}$ & $\begin{array}{l}-1.8315 \\
{[0.3071]}\end{array}$ \\
\hline
\end{tabular}

NOTE; LY = log of real GDP per capita, PCB = principal component of banking sector development, PCS = principal component of stock market development, $\mathrm{LTO}=\log$ of trade openness, LCAO $=\log$ of capital account openness, LINST $=\log$ of government effectiveness, INT $=$ simultaneous opening of trade and capital accounts, D2 = dummy for developed countries. $\mathrm{N}=53$. Values in ( ) and [ ] denotes standard errors and p-values respectively. ${ }^{* * *},{ }^{* *}$ denotes significance at $1 \%$ and $5 \%$ respectively.

Table 4. The result of two step dynamic panel GMM on the role of financial and trade openness on financial development (sample period: 1996-2013, averaged over 3 years).

\section{TWO STEP DIFF GMM}

TWO STEP SYSTEM GMM

$\begin{array}{ccc} & 0.3162 & 0.2676 \\ \text { PCS }_{t-1} & (0.1026) & (0.1001) \\ & {[0.006]} & {[0.003]} \\ \text { LY } & 2.3516 & 1.0908 \\ & (0.3732) & (0.1901) \\ & {[0.000]} & {[0.000]} \\ \text { PCB } & 0.1349 & 0.2016 \\ & (0.0003) & (0.0001) \\ & {[0.000]} & {[0.000]} \\ \text { LTO } & 0.8301 & -0.1536 \\ & (1.1606) & 0.4106) \\ & {[0.51]} & {[0.97]} \\ \text { LCAO } & -3.9917 & -5.0295 \\ & (2.0103) & (1.2131) \\ & {[0.051]} & {[0.000]} \\ \text { INT } & 1.9067 & 2.3901 \\ & (0.8407) & (0.3705) \\ & {[0.003]} & {[0.000]}\end{array}$




\section{Continued}

\begin{tabular}{ccc}
\hline LGE & -1.7843 & -1.5588 \\
& $(0.4123)$ & $(0.3296)$ \\
SARGAN TEST & {$[0.000]$} & {$[0.000]$} \\
& 21.0941 & 20.6732 \\
AR 2 & {$[0.033]$} & {$[0.197]$} \\
& -1.5563 & -1.7681 \\
& {$[0.4392]$} & {$[0.4807]$}
\end{tabular}

NOTE; LY = log of real GDP per capita, PCB = principal component of banking sector development, PCS = principal component of stock market development, LTO $=\log$ of trade openness, LCAO $=\log$ of capital account openness, LGE $=\log$ of government effectiveness, INT $=$ simultaneous opening of trade and capital accounts. $\mathrm{N}=53$. Values in ( ) and [ ] denotes standard errors and p-values respectively. ${ }^{* * * * *}$ denotes significance at $1 \%$ and $5 \%$ respectively.

Table 5. The result of two step dynamic panel GMM on the role of financial and trade openness on financial development (sample period: 1996-2013, averaged over 3 years).

\begin{tabular}{ccc}
\hline & TWO STEP DIFF GMM & TWO STEP SYSTEM GMM \\
\hline \multirow{2}{*}{ PCS $_{t-1}$} & 0.6198 & 0.4291 \\
& $(0.1091)$ & $(0.0537)$ \\
LY & {$[0.004]$} & {$[0.000]$} \\
& 1.9797 & 1.4516 \\
& $(0.3027)$ & $(0.1134)$ \\
PCB & {$[0.000]$} & {$[0.000]$} \\
& 0.0027 & 0.0019 \\
& $(0.0003)$ & $(0.0002)$ \\
LTO & {$[0.000]$} & {$[0.000]$} \\
& 0.1528 & 0.1997 \\
& $(1.0721)$ & $(0.4039)$ \\
LCAO & {$[0.978]$} & {$[0.625]$} \\
& -5.0056 & -4.2913 \\
& $(2.372)$ & $(1.3078)$ \\
INT & {$[0.034]$} & {$[0.000]$} \\
& 2.0636 & 1.9816 \\
& $(0.7655)$ & $(0.3610)$ \\
LVA & {$[0.002]$} & {$[0.000]$} \\
& -1.4388 & -1.4212 \\
SARGAN TEST 2 & $(0.4539)$ & $(0.3137)$ \\
& {$[0.000]$} & {$[0.000]$} \\
& 20.2317 & 22.5459 \\
& {$[0.045]$} & {$[0.269]$} \\
& -1.4068 & -1.1509 \\
& {$[0.4733]$} & {$[0.6670]$} \\
\hline
\end{tabular}

NOTE; LY = log of real GDP per capita, PCB = principal component of banking sector development, PCS = principal component of stock market development, LTO = log of trade openness, LCAO = log of capital account openness, LVA = log of voice and accountability, INT = simultaneous opening of trade and capital accounts. $\mathrm{N}=53$. Values in ( ) and [ ] denotes standard errors and p-values respectively. ${ }^{* * *}$, ${ }^{* * *}$ denotes significance at $1 \%$ and $5 \%$ respectively.

development. The result is similar to Law and Shah Habibullah [8].

Like trade openness, the expected impact of capital account openness on financial sector development and hence economic growth, is contentious. Supporters of capital account liberalization argue that it will lead to financial sector efficiency and development, while critiques of financial liberalization contest that it promotes financial instability and underdevelopment. The result buttresses the result of Diaz-Alejandro [10], and EichenGreen [7].

One finding that beats popular expectation is the effect of institutions on stock market development. The finding of a negative impact of institutions on stock market development does not appeal to common sense nor theoretical expectation. This however may be explained thus: better institutions may be associated with red-tapism and bureaucratic bottle-necks while weak institutions may speed up the process. Our finding is how- 
ever contrary to Baltagi et al. [9].

Interestingly, the finding of uneven impact of financial liberalization on stock market development is not surprising. Developed countries may stand to gain from capital account opening while developing countries may suffer from financial liberalization. The reasons for these are that the stock market is the major source of financing businesses in developed countries. Again, stock markets in developed countries are characterized by almost perfect information, which means that firms will not take undue advantage of market information asymmetry to generate undue gains and create volatility in the market. Also, there is conducive playing ground for all market participants.

On the other hand, stock markets in developing countries are highly volatile and investors are usually after short term profit. Again, the markets are highly imperfect and there are limited mechanisms to check the activities and excesses such as insider trading etc of the market participants. Further, economic and political together with policy inconsistencies lead to stock market under development.

Lastly, the results do not find support for the Simultaneous openness hypothesis. The results in Tables 1-5 reject the Rajan and Zingales [4] simultaneous openness hypothesis. They proposed that capital account and trade openness will be detrimental to financial sector development unless concurrently liberalized. The results in Tables 1-5 show that while the expected sign and impact of capital account and the interaction term are in line with Rajan and Zingales' proposition [4], trade openness is found to be inconsistent with. Therefore, this study rejects the Rajan and Zingales' simultaneous openness hypothesis.

\section{Conclusions}

While the role of financial development in the economic growth process has been widely acknowledged, there is contention as to the factors affecting financial sector development. One area of empirical divergence among scholars is on the area of liberalization and more specifically, financial liberalization. This paper investigates the impact of openness and institutional quality on stock market development.

Using annual data from 1996-2013 averaged over 3 years period in a sample of 53 countries and employing Dynamic GMM estimators, the results show that economic growth, banking sector development, and the interaction term affect stock market development positively while capital account openness and institutional quality negatively impact on stock market development. The effect of trade openness is mixed. The results do not find evidence in support Rajan and Zingales’ proposition of simultaneous openness hypothesis [4].

\section{References}

[1] Law, S.H. (2008) Does Country’s Openness to Trade and Capital Accounts Leads to Financial Development? Evidence from Malaysia. Asian Economic Journal, 22, 161-177. http://dx.doi.org/10.1111/j.1467-8381.2008.00273.x

[2] Chinn, D.M. and Ito, H. (2006) What Matters for Financial Development? Capital Controls, Institutions, and Interactions. Journal of Development Economics, 81, 163-192. http://dx.doi.org/10.1016/j.jdeveco.2005.05.010

[3] Baltagi, H.B., Demetriades, P.O. and Law, S.H. (2007) Financial Development and Openness: Evidence from Panel Data. Journal of Development Economics, 89, 285-296. http://dx.doi.org/10.2139/ssrn.1026323

[4] Rajan, R.G and Zingales, L. (2003) The Great Reversal: The Politics of Financial Development in the Twentieth Century. Journal of Financial Economics, 69, 5-50. http://dx.doi.org/10.1016/S0304-405X(03)00125-9

[5] Beck, T. and Levine, R. (2005) Legal Institutions and Financial Development. Handbook of New International Economics, 251-278. http://dx.doi.org/10.1007/0-387-25092-1_12

[6] Arestis, P., Demetriades, P., Fattouh, B. and Mouratidis, K. (2002) The Impact of Financial Liberalization Policies on Financial Development: Evidence from Developing Economies. International Journal of Finance and Economics, 7, 109-121. http://dx.doi.org/10.1002/ijfe.181

[7] Eichen-Green, B. (2001) Capital Account Liberalization: What Do Cross Country Studies Tell Us? The World Bank Economic Review, 15, 341-365. http://dx.doi.org/10.1093/wber/15.3.341

[8] Law, S.H. and Shah Habibullah, M (2009) The Determinant of Financial Development: Institutions, Openness, and Financial Liberalization. South African Journal of Economics, 77, 1. http://dx.doi.org/10.1111/j.1813-6982.2009.01201.x

[9] Baltagi, H.B., Demetriades, P.O. and Law, S.H. (2009) Financial Development, Openness, and Institutions: Evidence from Panel Data. World Economy and Finance Research Programme, Working Paper Series, WEF0022.

[10] Diaz-Alejandro, C. (1985) Good-Bye Financial Repression, Hello Financial Crash. Journal of Development Economics, 19, 1-24. http://dx.doi.org/10.1016/0304-3878(85)90036-7 
[11] Ben Neceau, S., Ghazouni, S. and Omran, M. (2008) Does Stock Market Liberalization Spur Financial Development and Economic Growth in the MENA Region? Journal of Comparative Economics, 36, 673-693. http://dx.doi.org/10.1016/j.jce.2007.12.002

[12] Bekaert, G., Harvey, C.R. and Lundblad, R. (2005) Does Financial Development Spur Growth? Journal of Financial Economics, 77, 3-55. http://dx.doi.org/10.1016/j.jfineco.2004.05.007

[13] Goh, S.K., Alias, M.H. and Olekalns, N. (2003) New Evidence on Financial Openness in Malaysia. Journal of Asian Economics, 14, 311-325. http://dx.doi.org/10.1016/S1049-0078(03)00026-5

[14] Levine, R. and Zervos, S. (1998) Stock Markets, Banks, and Economic Growth. The American Economic Review, 88, 537-558.

[15] Gries, T., Kraft, M. and Meierrieks, D. (2009) Linkages between Financial Deepening, Trade Openness, and Economic Growth: Causality Evidence from Sub-Saharan Africa. World Development, 37, 1849-1860. http://dx.doi.org/10.1016/j.worlddev.2009.05.008

[16] Umutlu, M., Akdeniz, L. and Attay-Salih, A. (2010) The Degree of Financial Liberalization and Aggregated Stock Return Volatility in Emerging Markets. Journal of Banking and Finance, 34, 509-521.

[17] Ahmed, A.D. and Suardi, S. (2009) Macroeconomic Volatility, Trade, and Financial Liberalization in Africa. World Development, 37, 1623-1636. http://dx.doi.org/10.1016/j.worlddev.2009.03.009

[18] Lim, K.P. and Kim, J.H. (2011) Trade Openness and the Informational Efficiency of Emerging Stock Markets. Economic Modelling, 28, 2228-2238. http://dx.doi.org/10.1016/j.econmod.2011.06.004

[19] Bley, J. and Saad, M. (2011) The Effect of Financial Liberalization on Stock Market Return Volatility in GCC Markets. Journal of International Financial Markets, Institutions, and Money, 21, 662-685. http://dx.doi.org/10.1016/j.intfin.2011.04.003

[20] Blundell, R. and Bond, S. (1998) Initial Conditions and Moment Restrictions in Dynamic Panel Data Models. Journal of Econometrics, 87, 115-143. http://dx.doi.org/10.1016/S0304-4076(98)00009-8

[21] Arellano, M. and Bond, S. (1991) Some Tests of Specification for Panel Data: Monte Carlo Evidence and an Application to Employment Equations. The Review of economic Studies, 58, 277-297. http://dx.doi.org/10.2307/2297968

[22] Arellano, M. and Bover, O. (1995) Another Look at the Instrumental Variable Estimation of Error-Components Models. Journal of Econometrics, 68, 29-51. http://dx.doi.org/10.1016/0304-4076(94)01642-D

[23] Chakraborty, I. (2008) Does Financial Development Cause Economic Growth? The Case of India. South Asia Economic Journal, 9, 109-139. http://dx.doi.org/10.1177/139156140700900105

[24] Ibrahim, M.H. (2008) Finance, Financial Volatility, and Economic Growth: Time Series Evidence from Malaysia. Global Review of Business and economic Research, 4, 211-223. 